\title{
RESEARCH INTO USAGE EFFICIENCY OF THE PULSATION MACHINE WITH A VIBRATING ROTOR FOR MILK HOMOGENIZATION
}

\author{
Kyrylo Samoichuk \\ Department of Processing and Food Production Equipment \\ Tavria State Agrotechnological University \\ 18 B. Khmelnistskiy ave., Melitopol, Ukraine, 72312 \\ samanyakir@mail.ru \\ Sergey Kiurchev \\ Department of Technology of Construction Materials \\ Tavria State Agrotechnological University \\ 18 B. Khmelnistskiy ave., Melitopol, Ukraine, 72312 \\ dec.tgatu@mail.ru \\ Vadym Oleksiienko \\ Department of Processing and Food Production Equipment \\ Tavria State Agrotechnological University \\ 18 B. Khmelnistskiy ave., Melitopol, Ukraine, 72312 \\ aleks.vadi65@yandex.ua \\ Nadiya Palyanichka \\ Department of Processing and Food Production Equipment \\ Tavria State Agrotechnological University \\ 18 B. Khmelnistskiy ave., Melitopol, Ukraine, 72312 \\ palyanichkan@gmail.com \\ Valentina Verholantseva \\ Department of Processing and Food Production Equipment \\ Tavria State Agrotechnological University \\ 18 B. Khmelnistskiy ave., Melitopol, Ukraine, 72312 \\ milaeva.v@mail.ru
}

\footnotetext{
Abstract

The modification of rotor-pulsation machine - pulsation machine with a vibrating rotor (PM with VR) has been researched in the work. Rotor in such modification not only rotates but also oscillates axially with the frequency about $3000 \mathrm{~min}^{-1}$ and amplitude $0,5-1,0 \mathrm{~mm}$. The aim of this research was to define specific features of milk homogenization process in PM with VR and disperse characteristics of milk emulsion.

Analytical researches resulted in finding dependence of milk emulsion acceleration as a main factor of milk fat particles breakup subject to the design and kinematic parameters of PM with VR. Experimental researches were carried out on the laboratory setup of the pulsation machine with a vibrating rotor which was designed by the authors. The subject of experimental researches is cow's milk. The sizes of milk fat globules after homogenization were measured by the optical microscope equipped with a digital camera.

The researches resulted in defining characteristics of milk emulsion dispersing in PM with VR. Thus acceleration grows when diameter, oscillation amplitude and rotation frequency of the rotor are increased, and channels length of the rotor and stator, the gap between them are decreased and the number of rotor openings is 4 or less.

Empirical dependence between the average diameter of the fat globule $(0,7-1,9 \mu \mathrm{m})$ and the average emulsion acceleration $((1-10) \times$ $\times 10^{3} \mathrm{~m} / \mathrm{s}^{2}$ ) in the interrupter of PM with VR is defined which proves that the emulsion flow acceleration is the main cause of homogenization of PM with VR with $92 \%$ confidence. High quality of the milk emulsion after processing in PM with VR has been proved. The crankshaft rotation frequencies up to $2880 \mathrm{rpm}$ and rotor oscillation amplitude of $1 \mathrm{~mm}$ enable to receive milk emulsion with the average dispersion about $0,8 \mu \mathrm{m}$ that corroborates using PM with VR in the industrial conditions for milk homogenization to be perspective.

Keywords: method of dispersion determination; homogenization of milk, homogenizer, pulsation machine with a vibrating rotor. 


\section{Introduction}

Milk homogenization in the modern dairy production schemes is one of the normative operations $[1,2]$. The advantages of homogenization are in increasing nutrition and organoleptic properties of milk [3]. Machines for homogenization - homogenizers differ in either high energy consumption (up to $8 \mathrm{~kJ} / \mathrm{t}$ ) or low level of milk emulsion dispersing [4,5]. High pressure homogenizers differ in high quality processing and high energy consumption. They are valve, ultra-high pressure homogenizers, microfluidizers [6]. Vacuum, ultrasonic, rotor, vortex et al. constitute another group of machines [2, 5, 6].

Recently rotor-pulsation machines have become widespread [7]. They consist of the rotor and stator with openings. When the openings of the rotor and stator periodically coincide the pulsation of the liquid and cavitation effects appear. In addition heavy gradient of velocity, high turbulence appear in the small gap between the rotor and stator. Dispersing of the dispersed phase of emulsion for instance milk takes place due to the combined action of these factors [7]. Disadvantage of such machines which homogenize milk is inhomogeneous composition of the dispersed phase [7]. Therefor such machines are used for dispersing viscous products. One of the modifications of rotor-pulsation machines is the pulsation machine with a vibrating rotor (PM with VR). Rotor in such modification not only rotates but also oscillates axially with the frequency about $3000 \mathrm{~min}^{-1}$ and amplitude 0,5-1,0 mm. [8]. The analytical researches were carried out for such machine [9-11], but the lack of experimental researches does not allow draw the conclusions about its efficiency for milk homogenization. Therefore the aim of the work is to define specific features of the milk homogenization process in PM with VR and disperse characteristics of milk emulsion.

The tasks of the research were:

- analytical definition of dependence of milk emulsion acceleration as a main cause of milk fat particles breakup on design and kinematic factors of PM with VR;

- experimental finding of dependence of diameter of milk fat globules on acceleration of milk emulsion and design and kinematic factors of PM with VR;

- experimental definition of dispersed rates of milk emulsion after processing in PM with VR.

\section{Materials and Methods}

\section{1. Methods of theoretical researches, design model and operating principle of the} machine

Theoretical dependence between design, kinematic and technological factors of PM with VR is determined by classical dependence of hydraulic and mechanic theories of discrete-impulse input of energy, oscillations of conservative linear systems.

PM with VR consists of cylindrical rotor and stator with the openings, set with a gap $\delta$ size of which is $0,2-0,5 \mathrm{~mm}$ (Fig. 1).

The channel of rotor $1_{p}$, gap between the cylinders and channel of stator $l_{c}$, make the length of channels of the modulator. The number of openings in the rotor and stator $\mathrm{z}$ is equal in order to fulfill the equality condition of pulsations of milk emulsion in each channel. For the same purpose diameters of openings of the rotor $d_{p}$ and stator $d_{c}$ are equal. A crank gear serves to create rotor vibration. The electric motor of rotor rotation drive is connected to the rotor shaft by a cone belt drive. Such drive allows displacement of 1-2 $\mathrm{mm}$ at rotor oscillations (vibrations) along the rotation axis.

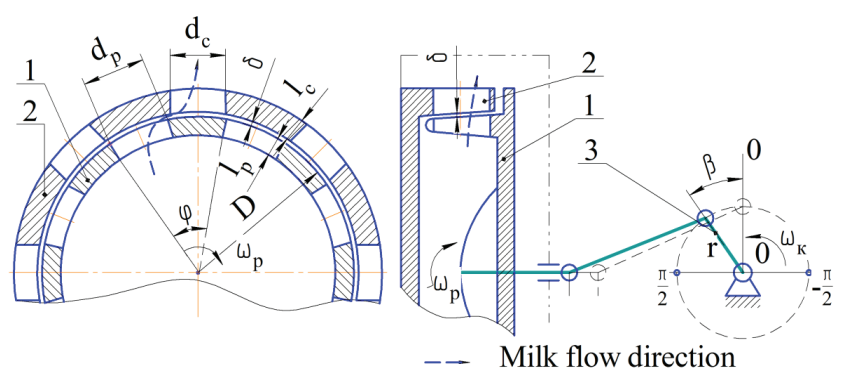

Fig. 1. Design model of PM with VR: 1 - rotor; 2 - stator; 3 - crank gear of rotor vibration drive 
While rotor is rotating its openings periodically coincide with and overlap the openings of the stator, changing the square of flow section of the rotor-pulsation machine (RPM) interrupter. While rotor is rotating with vanes, set inside the rotor, centrifugal pressure of liquid is created. At the periodic square change of the interrupter the pulsations of pressure and velocity of milk occur in its channels. While rotor is vibrating along its own axis the pulsations of pressure appear as well. Frequency of rotor rotation is coordinated with the rotation frequency of the crankshaft so that these pulsations overlap and intensify each other.

\section{2. Methods of experimental researches, subject of research and method of determi-} nation of dispersed characteristics of milk emulsion

As an subject of research we used whole cow's milk (check) with a fat content of 3,2-4,5\% with the average size of fat globules $2,4-3,1 \mu \mathrm{m}$.

The sizes of milk fat globules after homogenization were measured by means of optical microscope equipped with the digital camera [12]. The sampling of milk was diluted with the distilled water in the proportion of 1:10. To increase the accuracy three solutions from every sample of emulsion were prepared, and from each solution there were 2 preparations. Received digital representations were processed by the computer program of analysis of images for determination of the amount of fat globules and their sizes (processor Intel ${ }^{\circledR}$ Pentium $\AA /$ Celeron $\AA / \mathrm{Xeon}^{\mathrm{TM}}$, AMD K6/Athlon ${ }^{\mathrm{TM}} /$ Duron $^{\mathrm{TM}} / \mathrm{Sempron}^{\mathrm{TM}}$ or compatible $500 \mathrm{MHz}$ or higher; at least $128 \mathrm{MB}$ RAM; video card and monitor $800 \times 600$ or higher-resolution). Each experiment was repeated 3 times, the arithmetic average was whereupon determined and rough errors were being checked (by the method of estimation of maximal divergences of results of the experiments).

\section{3. Design of the experimental setup for milk homogenization in PM with VR}

For carrying out experimental research the laboratory setup of PM with VR (Melitopol city, Ukraine) was developed [8, 13], its scheme and design are shown in Fig. 2, 3, and structure of the homogenizing unit - in Fig. 4.

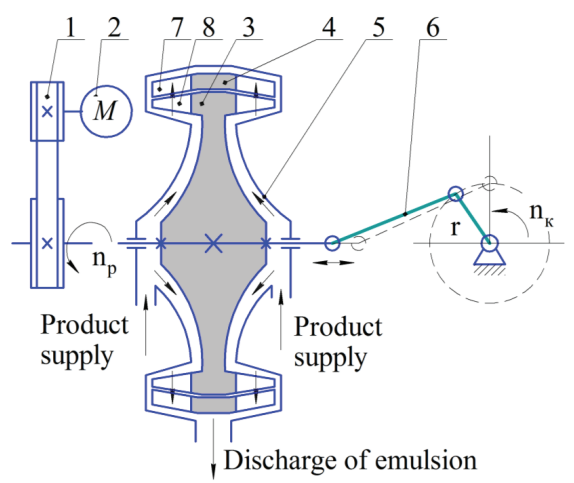

Fig. 2. Scheme of the pulsation machine with a vibrating rotor: 1 - cone belt transmission; 2 - electric motor of the rotor rotation drive, 3 - rotor; 4 - stator; 5 - body; 6 - crank gear of the rotor vibration; 7 - openings of the stator; 8 - openings of the rotor

The electric motor of direct current was used to enable rotation frequency change. Rotor vibration amplitude was being changed by adjusting the radius of the crankshaft rotor vibration drive. Vanes, set in the cavity of rotor and grooves allow use the machine without external pump, unlike typical RPM.

Working chamber of PM with VR (Fig. 3) contains the vanes 3 for increasing the pump effect and channels, which allow such RPM work without any additional pumps. In the enclosure creates positive pressure of liquids, on force of which product take off from settings through the branch pipe 1. Radial openings of rotor 8 and stator 6 create necessary pulsation of liquid, thus forming modulator of PM. In channels 9 the emulsion streams realize impact that additionally 
increases the efficiency of the product emulsification. Pass valve 7 is necessary for filling homogenizing unit working area with the product at launching time.

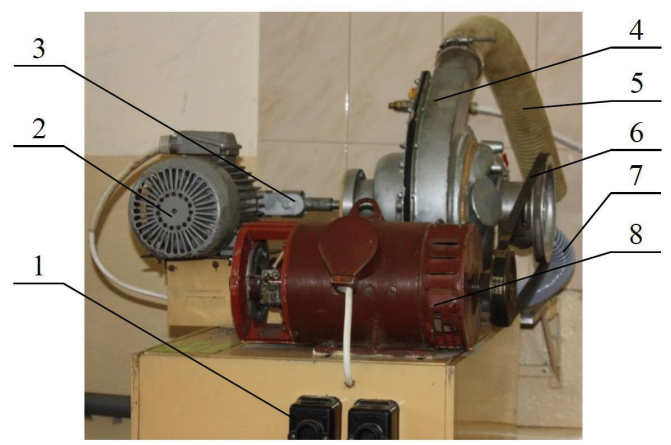

Fig. 3. General view of the experimental setup of PM with VR: 1 - control stand;

2 - electric motor of rotor vibration drive; 3 - crank gear; 4 - homogenizing unit; 5 - branch pipe of the product discharge; 6 -cone belt transmission of rotation of rotor; 7 - branch pipe of milk supply; 8 - electric motor of the rotor rotation drive

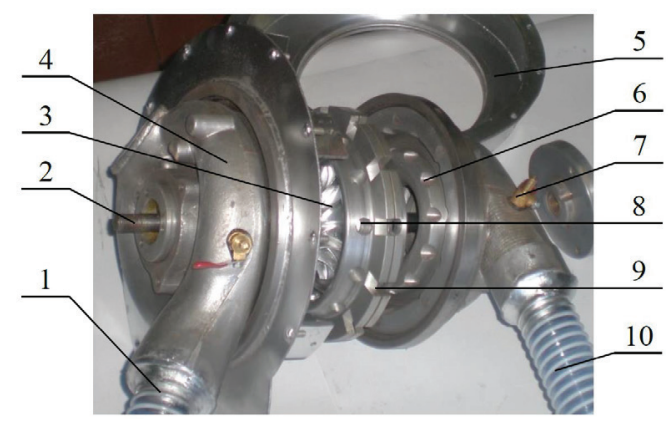

Fig. 4. Structure of the homogenizing unit of the pulsation machine with a vibrating rotor: 1 - branch pipe of the product discharge; 2 - rotor axis; 3 - vanes; 4 - body; 5 - cover; 6 - stator; 7 - pass valve; 8 - openings of the rotor; 9 - grooves of the rotor; 10 - branch pipe of the product supply

\section{4. Choosing factors for carrying out experimental researches}

While conducting experimental researches variable factors were chosen:

- rotation frequency of the crank shaft $\omega_{\mathrm{K}}$ (the range of changing is $150-300 \mathrm{~s}^{-1}$ );

- radius of the crank $r$ (the range of changing is $0,5-1,5 \mathrm{~mm}$ ).

Rotation frequency of the rotor was set according to the formula $\omega_{\mathrm{p}}=\omega_{\mathrm{K}} / 6$ for the setting operation in the resonance mode. With the same aim the difference was set between the angles of the crank turning $\beta$ and rotor rotation $\varphi$ (Fig. 1) equivalent to $270^{\circ}$. Constancy of this was controlled before the beginning of every experiment by marks on the rotor shaft, crank and body of the rotor.

Invariable factors: diameter of rotor $\mathrm{D}=0,15 \mathrm{~m}$, number of openings in the rotor (and stator) $\mathrm{z}=6$, gap between the rotor and stator $\delta=1 \mathrm{~mm}$, length of the rotor $\mathrm{l}_{\mathrm{p}}=5 \mathrm{~mm}$, length of the stator $1_{c}=10 \mathrm{~mm}$.

\section{Results}

The analytical researches conducted beforehand resulted in defining equation of the emulsion movement velocity $v_{0}$ through the interrupter of the machine [9], with condition of creating resonance phenomena. It increases homogenization efficiency by means of increasing amplitude of emulsion pulsations in the interrupter. The condition of resonance creation is making equality $\omega_{\mathrm{p}}=\omega_{\mathrm{K}} / \mathrm{z}$ or $\varphi=\beta / \mathrm{z}$ and phase shear angle between the rotation of the rotor and $\operatorname{crank} \beta=3 \pi / 2[10]$. 


$$
v_{o}=\frac{60 \omega_{\mathrm{K}} \mathrm{rD} \cos (\beta-3 \pi / 2)}{\frac{\pi^{2} \mathrm{D}}{2 \mathrm{z}}\left(1+\sin \left(\beta-\frac{\pi}{2}\right)\right)+8 \pi \delta}+\frac{\pi \omega_{\mathrm{p}} \mathrm{D}^{2}}{4 \mathrm{z}\left(\mathrm{l}_{\mathrm{p}}+\delta+\mathrm{l}_{\mathrm{c}}\right)}\left\{\frac{\beta}{2 \pi}\right\}
$$

where $\beta, \varphi$ - turning angle of the crank shaft and rotor correspondingly, radians; $\omega_{\mathrm{k}}, \omega_{\mathrm{p}}$ - rotation frequency of the crank shaft and rotor correspondingly, $\mathrm{s}^{-1}$; D - diameter of the rotor, $\mathrm{m} ; \mathrm{r}$ - radius of the crank, $\mathrm{m} ;\{\varphi \mathrm{z} / 2 \pi\}$ - fractional part of the number $\varphi \mathrm{z} / 2 \pi$.

To find the acceleration a the equation (1) has to be differentiated taking into account that $\mathrm{dt}=\left(1 / \omega_{\mathrm{\kappa}}\right) \mathrm{d} \beta$

$$
\begin{gathered}
\mathrm{a}=\frac{\mathrm{d} v_{\mathrm{o}}}{\mathrm{dt}}=\frac{\pi \omega_{\mathrm{K}}^{2} \mathrm{D}^{2}}{4 \mathrm{z}^{2}\left(\mathrm{l}_{\mathrm{p}}+\delta+\mathrm{l}_{\mathrm{c}}\right)}- \\
-\frac{30 \omega_{\mathrm{K}}^{2} \mathrm{Dr}\left[\frac{2 \mathrm{~K}}{\pi} \sin \left(\omega_{\mathrm{K}} \mathrm{t}-\frac{3 \pi}{2}\right)+\frac{\mathrm{D}}{\mathrm{z}} \cos \left(\omega_{\mathrm{K}} \mathrm{t}-\frac{3 \pi}{2}\right) \cos \left(\omega_{\mathrm{K}} \mathrm{t}-\frac{\pi}{2}\right)\right]}{\mathrm{K}^{2}},
\end{gathered}
$$

where $\mathrm{K}=\frac{\pi \mathrm{D}}{2 \mathrm{z}}\left(1+\sin \left(\omega_{\mathrm{K}} \mathrm{t}-\frac{\pi}{2}\right)\right)+8 \delta-$ is the coefficient which characterizes the change of geometry of the modulator of PM with VR in course of time, $\mathrm{m}$.

At $0,0026<t<0,0182 \mathrm{~s}$ acceleration changes sharply on parabolic dependence that indicates much better conditions for fat phase dispersing. So the average acceleration $a_{c}$ is determined for the worst conditions of the fat globules breakup that corresponds to $t=0,0026-0,0182 \mathrm{~s}$, where the acceleration almost does not change

$$
a_{c}=\omega_{\kappa}^{2} D^{2}\left(\frac{\pi}{4 z^{2}\left(l_{p}+\delta+l_{c}\right)}+\frac{30 r}{z\left(\frac{\pi D}{2 z}+8 \delta\right)^{2}}\right)
$$

It is easy to see from the got expression (3) that the biggest influence on the acceleration is rendered by rotation frequency of the crank $\mathrm{a}_{\mathrm{c}} \sim \omega_{\mathrm{K}}{ }^{2}$. Increase of radius of the crank results in the scaling-up of the second summand (3).

The amount of openings $z$ determines rotation frequency of the rotor $\left(\omega_{\mathrm{p}}=\omega_{\mathrm{K}} / \mathrm{z}\right)$, that is why it substantially influences $a_{c}$. Connection between the acceleration and diameter of rotor can be approximately denominated as $\mathrm{a}_{\mathrm{c}}$ that is proportional to $\mathrm{D}$.

The minimal acceleration is on $z=6 \ldots 8$. Diminishing the amount of openings to 4 makes the acceleration grow substantially, and the nature of dependence is similar to linear. In the range of $\mathrm{z}=7 \ldots 12$ the acceleration scales up, and the nature of dependence can be considered as $\mathrm{a}_{\mathrm{c}}=\mathrm{f}(\mathrm{z})$ which is similar to parabolic.

Thus maximal conditions for crushing milk fat globules are created at $z=4,\left(\omega_{\mathrm{K}}, \mathrm{r}, \mathrm{D}\right) \rightarrow \max$, and $\left(\delta, 1_{p}, 1_{c}\right) \rightarrow$ min. Range of fluctuations of parameters $\delta, 1_{p}, 1_{c}$ is small $\left(\delta=0,8-1,0 \mathrm{~mm} ; 1_{p}=8-12 \mathrm{~mm}\right.$; $1_{c}=15-20 \mathrm{~mm}$ ), thus their influence on $\mathrm{a}_{\mathrm{c}}$ is insignificant.

In the experimental part of research at combining variable factors (rotation frequency and radius of the crank) the value of the average acceleration of milk emulsion $a_{c}$ (according to the formula (3)) and the average size of milk fat globules were being determined (Fig. 5).

Results with $92 \%$ confidence are approximated by expression (in Fig. $\mathbf{5}$ it is shown with a dashed line)

$$
\mathrm{d}=\frac{68}{\sqrt{\mathrm{a}}} .
$$


Let's compare the results of theoretical and experimental data of the average sizes of fat globules depending on the rotor rotation frequency and amplitude of its oscillation (Fig. 6).

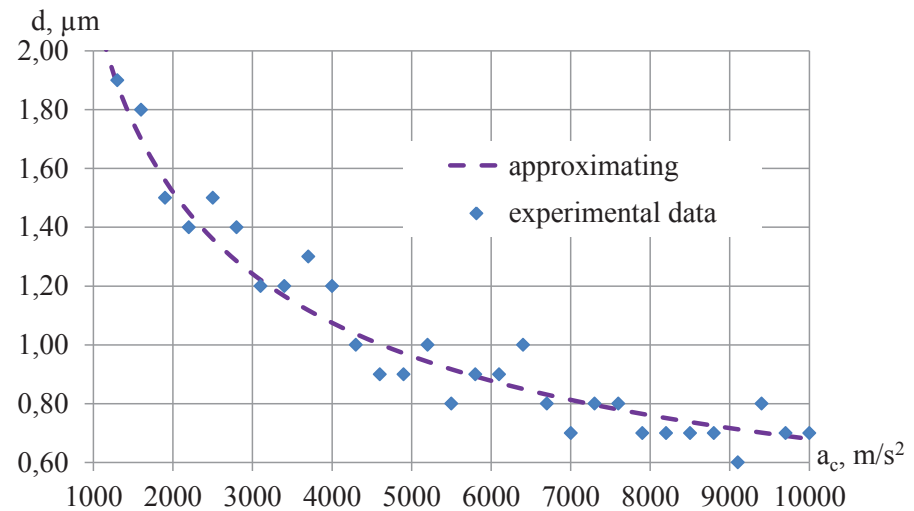

Fig. 5. Dependence between the average diameter of fat globules d after homogenization and acceleration of milk emulsion $\mathrm{a}_{\mathrm{c}}$

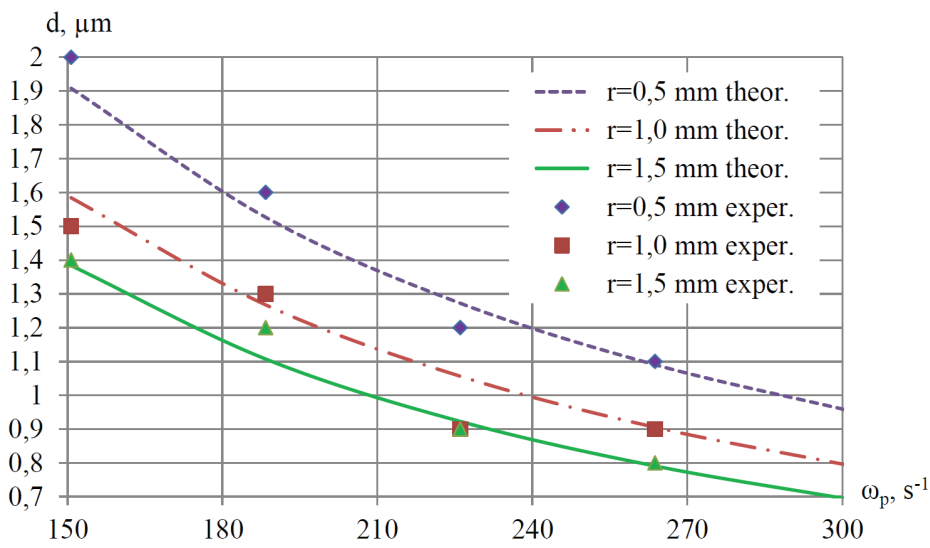

Fig. 6. Dependence of the average size of milk fat globules $d$ on the frequency of rotation $\omega_{p}$ and radius of the crank $r$

According to the dependences shown in Fig. $\mathbf{6}$ it is possible to get identical dispersion at different $\omega_{\mathrm{k}}$ and $\mathrm{r}$. For example it is possible to get $\mathrm{d}=0,8 \mu \mathrm{m}$ when $\mathrm{r}=1,5 \mathrm{~mm}, \omega_{\mathrm{k}}=260 \mathrm{~s}^{-1}$ and when $\mathrm{r}=1,0 \mathrm{~mm}, \omega_{\mathrm{k}}=300 \mathrm{~s}^{-1}$.

According to the results of researches of energy consumption of PM with VR the operation modes with the minimum $r$ will be optimal [11]. At such modes energy consumption is minimal. Thus when $\mathrm{r}=1,0 \mathrm{~mm}$ (which equals amplitude of oscillation $2 \mathrm{~mm}$ ) specific energy consumption of the process is less. Thereby in designing industrial models of PM with VR it is necessary to choose operation modes with the minimal amplitude of rotor vibration as a rational mode of homogenization.

Fractional composition of fat globules after homogenization in PM with VR at $\mathrm{n}_{\mathrm{k}}=2880 \mathrm{rpm}$, $\mathrm{r}=1 \mathrm{~mm}$ (at which optimal balance between quality and energy efficiency is reached) has been compared to the valve homogenization at pressure $16 \mathrm{MPa}$ (the most energy efficiency value of pressure) (Fig. 7, 8).

Milk before homogenization is characterized with the following parameters: average diameter of fat globules $\mathrm{D}=2.6 \mu \mathrm{m}$, dispersion $\sigma=1.7$, variation coefficient (part of spreading the feature relative to the average) $\mathrm{V}=68 \%$. Accordingly we got the following parameters of milk after homogenization in PM with VR and valve homogenizer A1-ОГ $2 \mathrm{M}: \mathrm{D}=0.8 \mu \mathrm{m}$ and $0.9 \mu \mathrm{m}, \sigma=0.38$ and $0.44, \mathrm{~V}=46$ and $49 \%$ correspondingly (Fig. 8). 


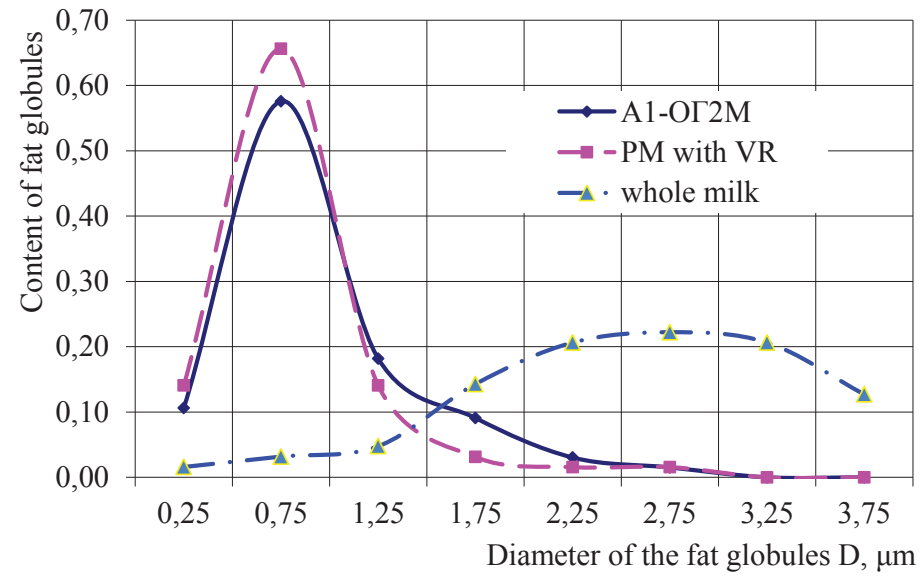

Fig. 7. Fractional composition of milk prior to homogenization and after homogenization in PM with VR and valve homogenizer А1-ОГ2M (Odessa mechanical plant, Ukraine)

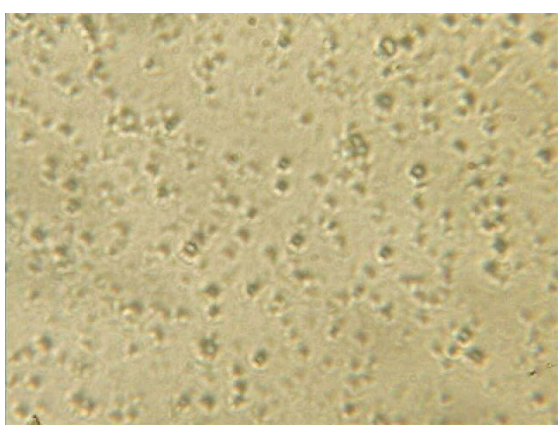

$a$

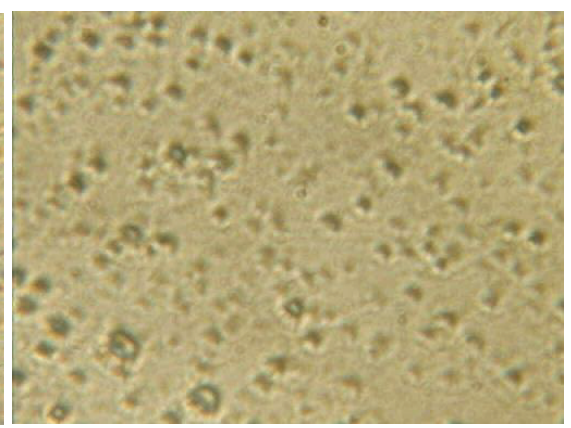

$b$

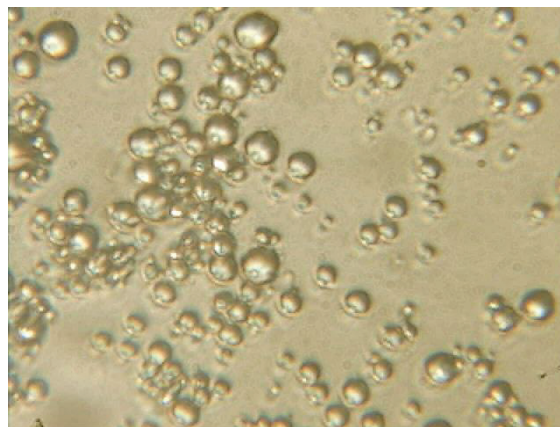

$c$

Fig. 8. Microphotography of milk sample (magnification degree $\times 400$ times): $a$ - after homogenization in PM with VR at $\mathrm{n}_{\mathrm{k}}=2880 \mathrm{rpm}, \mathrm{r}=1 \mathrm{~mm} ; b$ - after valve homogenizer at pressure $16 \mathrm{MPa} ; c$ - whole milk (check)

Average diameter of fat globules when processed in PM with VR decreased by $11 \%$ compared with valve, value of dispersion decreased by $6 \%$ which indicates increasing quality of homogenized emulsion.

\section{Conclusions}

1. The characteristics of milk emulsion dispersing in PM with VR were determined. They consist in increasing acceleration when the diameter, oscillation amplitude and rotor rotation frequency are increased, and length of the rotor channels, stator and gap between them are decreased and the amount of rotor openings is 4 or less. 
2. The scheme and design of the laboratory setup of PM with VR for milk homogenization researches was developed. The method of determining dispersed rates of milk emulsion by the optical microscope, digital camera and computer was grounded.

3. The empiric dependence between the average diameter of the fat globule $(0.7-1.9 \mu \mathrm{m})$ and average emulsion acceleration $\left((1-10) \cdot 10^{3} \mathrm{~m} / \mathrm{s}^{2}\right)$ in the interrupter of PM with VR is defined, which proves with $92 \%$ confidence that the emulsion flow acceleration is the main cause of homogenization in PM with VR.

4. High quality of milk emulsion after processing in PM with VR has been proved. At frequencies of rotation of the crank shaft up to $2880 \mathrm{rpm}$ and amplitude of rotor oscillation $1 \mathrm{~mm}$ it is possible to get milk emulsion with the average size of about $0.8 \mu \mathrm{m}$ that testifies for the perspective usage of PM with VR in the industrial conditions for homogenization of milk.

5. Experimental results of the research into dispersed composition of milk after processing in PM with VR and their comparison with valve homogenization (the quality of which is completely satisfying for any processes of the dairy industry $[1,3,4]$ ) testify to the advantage of processing in PM with VR. Moreover these indexes are reached at specific energy consumption which is considerably less than in valve homogenizers [11]. The results received prove that PM with VR can substitute valve homogenizers which exist in the world industry in milk processing.

Future researches are planned to define efficiency of PM with VR for processing viscous products (creams, mixes for producing ice-cream, mayonnaise).

\section{References}

[1] Wilbey, R. A. (2011). Homogenization of milk. Principles and Mechanism of Homogenization, Effects and Assessment of Efficiency: Valve Homogenizers. Encyclopedia of Dairy Sciences, 750-754. doi:10.1016/ b978-0-12-374407-4.00223-5

[2] Huppertz, T. (2011). Homogenization of milk. Other Types of Homogenizer (High-Speed Mixing, Ultrasonics, Microfluidizers, Membrane Emulsification). Encyclopedia of Dairy Sciences, 761-764. doi:10.1016/ b978-0-12-374407-4.00226-0 dom, 264

[3] Nuzhin, E. V., Gladushnyak, A. K. (2007). Gomogenizatsiya i gomogenizatoryi. Pechatnyiy

[4] Wilbey, R. A. (2002). Homogenization of milk. Encyclopedia of Dairy Sciences, 1346-1349. doi: 10.1016/b0-12-227235-8/00202-9

[5] Liu, C., Li, M., Liang, C., Wang, W. (2013). Measurement and analysis of bimodal drop size distribution in a rotor-stator homogenizer. Chemical Engineering Science, 102, 622-631. doi:10.1016/j.ces.2013.08.030

[6] Brivibaa, K., Gräfc, V., Walzc, E., Guamisd, B., Butz, P. (2016). Ultra high pressure homogenization of almond milk: Physico-chemical and physiological effects. Food Chemistry, 192, 82-89. doi:10.1016/ j.foodchem.2015.06.063

[7] Promtov, M. A., Monastirsky, M. X. (2000). Dynamic of cavitational bubbles in rotor impuls apparatus. Journal of Qingdao Just of Chemistry Technical, 21 (4), 318-321.

[8] Samoichuk, K. O., Ivzhenko, A. O. (2013). Eksperymentalni doslidzhennia dysperhuvannia zhyrovoi emulsii v pulsatsiinomu aparati z vibruiuchym rotorom. Obladnannia ta tekhnolohii kharchovykh vyrobnytstv, 30, 155-161.

[9] Samoichuk, K. O., Ivzhenko, A. O. (2014). Opredelenye skorosty v moduliatore pulsatsyonnoho homohenyzatora s vybryruiushchym rotorom. Vestnyk Mohylëvskoho hosudarstvennoho unyversyteta prodovolstvyia, 1 (16), 87-99.

[10] Deinychenko, H. V., Samoichuk, K. O., Ivzhenko, A. O. (2016). Synkhronizatsiia kolyvalnykh i obertalnykh rukhiv rotora u pulsatsiinomu homohenizatori z vibruiuchym rotorom. Vibratsii v tekhnitsi ta tekhnolohiiakh, 1 (81), 122-131.

[11] Samoichuk, K. O., Ivzhenko A. O. (2013). Rozrakhunok enerhovytrat pulsatsiinoho aparata $\mathrm{z}$ vibruiuchym rotorom. Naukovi pratsi Odeskoi natsionalnoi akademii kharchovykh vyrobnytstv, 43 (2), 133-137.

[12] Samoichuk, K. O., Kovalov, O. O., Ivzhenko, A. O. (2012). Analiz metodiv otsiniuvannia yakosti homohenizatsii moloka. TDATU, 12 (4), 222-229.

[13] Samoichuk, K. O., Ivzhenko, A. O., Yalpachyk, F. Yu., Sultanova, V. O.; assignee: Tavria State Agrotechnological University. (25.04.2016). Rotorno-pulsatsiinyi aparat z rotorom, shcho vibruie. Patent UA, № 106554. МПК В01F 7/12 (2006.01). Filed 23.11.2015. Available at: http://ibrary.uipv.org/document?fund=2\&id=222873\&to_fund $=2$ 